DOI: $10.15593 / 978-5-398-02346-6 / 2020.04$

\title{
Н.Е. ОНЧУКОВ - КЛАССИК РУССКОЙ ФОЛЬКЛОРИСТИКИ
}

\author{
М.A. Шитова, \\ заведующий отделом мониторинга и популяризаџии \\ объектов культурного наследия, \\ Сарапульский историко-архитектурный \\ и художественный музей-заповедник, \\ Сарапул, Удмуртская Республика \\ metod-miksp@mail.ru
}

Аннотация. Рассказывается о судьбе одного из видных деятелей русской этнографии и фольклористики Николае Евгеньевиче Ончукове (1872-1942), уроженце города Сарапула, члене Русского географического общества, одного из основателей музея Сарапульского земства. После революции 1917 г. - преподавателе в институтах Перми и Ленинграда. В 30-е гг. Николая Евгеньевича дважды арестовывали. Умер в лагере под Пензой в 1942 г. Официально реабилитирован в 1989 г.

Ключевые слова: фольклористика; Русское географическое общество; Сарапул; сарапульский музей; издательское дело; убийство С.М. Кирова; репрессии.

\section{N.E. ONCHUKOV-CLASSIC OF RUSSIAN FOLKLORE}

\section{M.A. Shitova,} is the head of the department of monitoring and popularization of cultural heritage sites, Sarapul Historical, Architectural and Art Museum-Reserve, Sarapul, Udmurt Republic metod-miksp@mail.ru

\footnotetext{
Summary. N.E. Onchukov - Classic russian folklore Article tells about the fate of one of the prominent figures of Russian ethnography and folklore Onchukov Nikolai Evgenyevich (1872-1942), a native of Sarapul, a member of the Russian Geographical Society, one of the founders of the Sarapul Land Museum. After the 1917 revolution, he was a teacher at the institutes of Perm
} 
and Leningrad. In the 1930s, Nikolai Evgenyevich was arrested twice. He died in a camp near Penza in 1942. Officially rehabilitated in 1989.

Keywords: folklore; Russian Geographical Society; Sarapool; Sarapul Museum; Publishing; murder of S.M. Kirov; Repression.

Николай Евгеньевич Ончуков родился в городе Сарапуле Вятской губернии в марте 1872 г. Отец будущего фольклориста, Евгений Иванович, занимался торговлей, мать, Мария Владимировна, из семьи купцов Башмаковых, умерла, когда мальчику было всего три месяца. Мальчик сначала воспитывался у бабушки в поселке Воткинского завода. В 1878 г. он вместе с нею переехал в Сарапул к своему отцу. Здесь в возрасте семи лет Н.Е. Ончуков поступил учиться в приходское училище

В 1890 г. после окончания приходского и уездного училищ в Сарапуле Николай едет на обучение в Казанскую земскую фельдшерскую школу, которую оканчивает в 1893 г. Затем несколько лет работает фельдшером в различных деревнях Пермской и Вятской губерний. Переселившись в Пермь, Н.Е. Ончуков поступает на службу в больницу пересыльной тюрьмы. В пермский период своей жизни будущий ученый начинает сотрудничать в местных и столичных газетах. Журналистика, таким образом, стала первой областью, где проявились его гуманитарные наклонности.

На рубеже веков, уже зрелым человеком, Николай Евгеньевич переезжает в Петербург. Здесь на протяжении нескольких лет он печатал небольшие заметки в различных периодических изданиях («Неделя», «Сын отечества», «Северный курьер» «Новое время и др.). В это же время Н.Е. Ончуков наладил контакты с этнографическим отделением Русского географического общества. Нам неизвестно, как произошло это очень важное для него событие, но к лету 1900 г. у Н.Е. Ончукова установились настолько крепкие связи с этим научным учреждением, что с открытым письмом Русского географического общества он отправился в свою первую экспедицию - в Чердынский уезд знакомой ему Пермской губернии. Цель поездки - сбор материалов по этнографии. Путешествия по глухим уголкам России увлекли Н.Е. Ончукова, и на протяжении 1900-1907 гг. он совершил шесть путешествий по заданию Российского географического общества и «Отделения русского языка и словесности Императорской Академии наук». 
Книга «Печерские былины» сделала Н.Е. Ончукова известным в научных кругах. За это собрание сказок он был награжден малой золотой медалью Русского географического общества.

В 1905 г. Н.Е. Ончуков приступает к подготовке следующего издания - книги «Северные сказки», которая получила высокую оценку специалистов. За «Северные сказки» ученый был награжден большой золотой медалью Русского географического общества.

Малоизвестен факт знакомства Н.Е. Ончукова с М.М. Пришвиным. Роль Н.Е. Ончукова заключается в содействии становлению творческой индивидуальности М.М. Пришвина. Дело не только в том, что он открыл писателю край непуганых птиц, но научные работы этнографа помогли писателю при создании его первой книги и даже непосредственно отразились в тексте очерков.

В 1908 г. наступил новый период в жизни Н.Е. Ончукова. Он решил вернуться из Петербурга в родной Сарапул. Здесь ученый баллотировался гласным в городскую думу. С 1 марта 1909 г. он начал издавать и редактировать ежедневную общественно-политическую и литературную газету «Прикамская жизнь» - «газета прогрессивная и беспартийная», - говорилось в ее программной статье. Газета живо откликалась на актуальные местные вопросы: писала о судьбе Воткинского завода, которому грозило закрытие, о затянувшемся строительстве водопровода, о плане постройки железной дороги Казань - Екатеринбург, о наводнении, причинившем большой ущерб городу в 1914 г. «Прикамская жизнь» помогала своему читателю быть в курсе культурных новостей России. Здесь печатались материалы о Грибоедове, Пушкине, Гоголе, Некрасове, Белинском и др. Но больше всего на ее страницах помещалось сведений о жизни, нравственных и философских взглядах Л.Н. Толстого. Видимо, мировоззрение Л.Н. Толстого было в чем-то близко самому Н.Е. Ончукову. Но в газете мы не видим материалов, посвященных этнографии и фольклору, которые должны бы, казалось, появиться при издателе, давшем России «Печерские былины» и «Северные сказки». Видимо, это объясняется тем, что газета отнимала у издателя слишком много сил, времени и средств.

Помимо газеты, Н.Е. Ончуков занимался множеством других дел. Он явился одним из основателей Сарапульского земского музея (1909). Благодаря ему в фондах музея хранятся подшивки издаваемой им газеты «Прикамская жизнь за 1909-1916 гг. 
1909-1917 гг. в жизни ученого - это время, полностью отданное общественной и просветительской деятельности в родном крае, и заслуги его здесь неоспоримы. Фольклористика же надолго отодвинулась на второй план. Но все-таки именно в этот период он выпускает свою третью книгу, сделавшую ему имя в науке «Северные народные драмы».

11 марта 1917 г. газета «Прикамская жизнь» была закрыта, считается, что за проявленные издателем монархические настроения.

Октябрьская революция приводит к братоубийственной Гражданской войне. В августе 1918 г. Сарапул занимают белогвардейские и чехословацкие войска, в октябре город был освобожден Азинской дивизией 2-й армии Восточного фронта. В марте 1919 г. Колчаковская армия переходит в наступление, город вновь оказывается в руках белогвардейцев. 28 апреля Красная армия переходит в контрнаступление, и городское управление отдает приказ об эвакуации.

Николай Евгеньевич, уходя вслед за Колчаковскими войсками, оказывается в Перми и далее в Омске. Там временным источником его существования становится работа хроникером, репортером газеты «Заря». Газета пользовалась успехом у читающей омской публики, но работать в ней Н.Е. Ончукову пришлось всего около трех месяцев - в июне 1919 г. газета была закрыта.

Красная армия успешно продвигается на восток. Из Омска Николай Евгеньевич эвакуируется в Новосибирск и затем в Иркутск.

Обратный путь на запад был постепенным и долгим. Весной 1920 г. в Иркутской губернии эпидемия сыпного тифа, мобилизация всех медиков. Николай Евгеньевич направлен на борьбу с эпидемией в г. Мысовск (ныне г. Бабушкин, Бурятия) и семь месяцев работает эпидемфельдшером.

По возвращению в Иркутск он пытается повысить свою квалификацию на медицинском факультете университета, но не был принят из-за возраста (48 лет). Однако он поступает на исторический факультет того же университета. Вскоре Николай Евгеньевич становится профессорским стипендиатом при кафедре истории русской литературы, но примерно через год его выводят за штат, оставляя без денег и пайка. С трудом пережив тяжкие времена на случайных заработках, Николай Евгеньевич получает приглашение на кафедру русского языка и словесности педагогического фа- 
культета Пермского государственного университета. Здесь он работает преподавателем-ассистентом два года и в 1923 г. возвращается в Сарапул.

В декабре 1924 г. Николай Евгеньевич перебирается в Ленинград, где продолжает преподавательскую работу - читает курс фольклора и ведет семинары на факультете языкознания и материальной культуры Ленинградского государственного университета.

В Ленинграде он снова обретает семью - 9 апреля 1929 г. Николай Евгеньевич регистрирует брак с Анной Александровной Булавкиной.

Устоявшейся и, наконец, более или менее налаженной и благополучной жизни приходит конец. 1 сентября 1930 г. в его квартире на Аптекарском проспекте появляются вооруженные люди. Доцента Ончукова арестовывают. А.А. Булавкина пишет об этом аресте: «Суть предъявленного ему обвинения... сводилась к тому, что он писал против большевиков в газетах, попав в оккупацию Колчака /сохранилась одна заметка с его подписью/. Арест был вызван доносом полусумасшедшего человека, перечислившего в своем дневнике всех краеведов, работавших в Ленинградской секции краеведческого общества /Н.Е. служил в ней год секретаpeм/. Вся секция была арестована как “замышлявшая заговор против советской власти"».

Надо напомнить, что в 1929-1930 гг. существовали сразу два «дела краеведов» - разгром краеведческого движения набирал обороты.

Решение Особого совещания при Коллегии ОГПУ выносится почти через девять месяцев после ареста Ончукова, в мае, а Николаю Евгеньевичу оно вручается лишь через месяц 22 июня 1931 г.

Приговор неожиданно мягкий - три года ссылки на поселение в северный край. Первоначальным пунктом ссылки стал город Котлас (Архангельская область), позже его переводят немного южнее в маленький городок Никольск (сейчас Вологодская область).

Анна Александровна обращается с просьбой о досрочном возвращении мужа в правительственную комиссию по делам частных амнистий, возглавляемую старым большевиком Смидовичем.

Как это ни удивительно, но Анне Александровне удается добиться досрочного освобождения мужа. Можно предположить, что 
Смидович был знаком с деятельностью Н.Е. Ончукова - с 1927 по 1930 г. именно он руководил Центральным бюро краеведения.

26 июля 1932 г. Ончуков получает удостоверение в том, что он освобожден от административной высылки и имеет право свободного проживания на территории СССР.

Николай Евгеньевич возвращается в Ленинград. Но здесь у него возникает проблема с паспортом. За помощью он обращается к своему давнему знакомому, старому большевику Владимиру Дмитриевичу Бонч-Бруевичу, который пишет письмо первому секретарю Ленинградского обкома ВКП(б) С.М. Кирову.

Вмешательство Бонч-Бруевича помогло. Конечно, о преподавании речи быть не могло, и Н.Е. Ончуков устраивается на работу научным сотрудником в Институт языка и мышления к академику Н.Я. Марру.

1 декабря 1934 г. был убит Киров. По Ленинграду и области прокатилось громкое «эхо» этого убийства. Четыре тысячи наиболее враждебных элементов (по усмотрению НКВД) расстреливаются. Десять тысяч «менее враждебных» арестовываются и заключаются в лагеря и тюрьмы на срок от 8 до 10 лет. Более того: 27 февраля 1935 г. Управление НКВД по Ленинградской области издает циркуляр «О выселении контрреволюционного элемента из Ленинграда и пригородных районов». Высылке подлежало 10-12 тысяч человек - члены семей осужденных и другие люди, происхождение или мышление которых вызывало хотя бы малейшее подозрение у органов.

23 марта 1935 г. в эту мясорубку попадает и семья Н.Е. Ончукова. Воспользовавшись правом выбора города для жительства, Ончуковы выбирают Пензу.

В апреле 1935 г. Ончуковы покидают Ленинград, как оказалось, навсегда. В Пензе у семьи начинаются мытарства с квартирой. Во время их отъезда в командировку в Жигули их квартира была продана. По воспоминаниям А.А. Булавкиной еще до их возвращения новый хозяин заявлял, что выгонит из квартиры «какихто там ученых».

Для достижения своей цели хозяин пускает в ход доносы. В Пензе Ончуковы постоянно находились «под колпаком» НКВД. В начале осени 1939 г. на поминках у некоего Терентия священник Митрофаньевской церкви А.Н. Рожков наговорил лишнего. По- 
следовал донос. Рожкова арестовывают, и он начинает оговаривать всех мало-мальски знакомых подряд. Немедленно возникает «антисоветская группа церковников». Аресты следуют один за другим. На свет появляется уголовное дело № 11808-п.

Следствие заканчивается 18 января 1940 г., 17 марта начинается суд. Дело рассматривалось в закрытом заседании судейской коллегией по уголовным делам Пензенского областного суда.

Николай Евгеньевич был осужден на 10 лет и пять лет поражения в правах.

Наказание отбывал в пос. Ахуны близ Пензы (сейчас это микрорайон города), работал на торфоразработках. Из письма Николая Евгеньевича жене незадолго до смерти: «...Очень зябну на работе. До передачи еще осталось 6 дней, а у меня кроме хлеба ничего не осталось...Дует, дует... холодно, мерзну, башлык не согревает... ремонт крепкими суровыми нитками.. при ежедневной работе по несколько часов все рвется очень быстро. Палец все болит. Нужен бы покой ему, а я все в движении... Желаю тебе здоровья и благополучия и крепко тебя целую и горячо за все благодарю. Твой Николай» (2 февраля 1942 г.).

11 марта 1942 г. Николай Евгеньевич Ончуков скончался в лагере и был похоронен близ поселка Ахуны. Полностью реабилитирован лишь в 1989 г.

Книги Н.Е. Ончукова востребованы и сегодня.

\section{Список литературы}

1. Блаженкова Т.А., Сенаторов П.П. Николай Евгеньевич Ончуков. Неизвестные страницы жизни. Казань, 2015.

2. Иванова Т.Г. Русская фольклористика в биографических очерках. СПб., 1993. С. 168-187. 